\title{
Drodzy Czytelnicy! \\ Drogie Koleżanki, drodzy Koledzy!
}

Witamy na łamach drugiego numeru „Poliarchii” - czasopisma naukowego studentów Wydziału Studiów Międzynarodowych i Politycznych Uniwersytetu Jagiellońskiego. Po pierwszym numerze, który w całości poświęciliśmy tematyce polskiej („Studia Polonica”), zapraszamy do zapoznania się z wydaniem, w którym prezentujemy efekty różnorodnych i oryginalnych badań studentów WSMiP UJ.

$\mathrm{Z}$ dumą informujemy o czterech ważnych zmianach, które wprowadziliśmy w ostatnich miesiącach. Począwszy od numeru, który trzymacie w rękach, wszystkie artykuły publikowane na łamach „Poliarchii” przechodzą przez proces tzw. podwójnej „ślepej” recenzji (double-blindreview). Oznacza to, że recenzent i autor nie znają wzajemnie swoich personaliów, a wszyscy recenzenci pochodzą spoza Uniwersytetu Jagiellońskiego. System ten, nowatorski w przypadku pism studenckich, gwarantuje wysoki poziom merytoryczny „Poliarchii” - na jej łamach ukażą się wyłącznie najlepsze spośród studenckich artykułów. Drugą zmianą jest poszerzenie Rady Naukowej pisma - dołączyło do niej grono uznanych specjalistów reprezentujących najbardziej renomowane ośrodki badawcze na świecie. W drugim numerze „Poliarchii” pojawił się także po raz pierwszy artykuł w języku angielskim, co uznać należy za trzecią istotną zmianę. Deklarujemy chęć rozwijania tego kierunku i zachęcamy wszystkich studentów do przygotowywania tekstów w różnych językach obcych. W wielkim stopniu poszerza to bowiem zasięg oddziaływania pisma i zwiększa jego rolę w procesie cyrkulacji wiedzy naukowej. To zaś ściśle wiąże się z czwartą zmianą - „Poliarchia” stała się częścią Central and Eastern European Online Library (CEEOL), co jest istotnym krokiem w budowaniu prestiżu pisma, zwiększaniu jego rozpoznawalności, poszerzaniu dostępności i cytowalności.

Wszystkie te zmiany i powstanie drugiego numeru „Poliarchii” nie byłyby możliwe, gdyby nie pomoc wielu osób. Wyrazy wdzięczności należą się przede wszystkim recenzentom, których entuzjazm dla „Poliarchii” przerósł nasze oczekiwania. Dziękujemy wydawnictwu Księgarnia Akademicka za udaną współpracę. Dziękujemy również Bartoszowi Zawiślakowi za korektę tekstu w języku angielskim i abstraktów artykułów. Dziękujemy za współpracę autorom artykułów i zachęcamy do pamiętania o „Poliarchii””

Odrębne wyrazy podziękowania kierujemy w stronę naszych darczyńców: Dziekana WSMiP UJ, Pana prof. dr. hab. Bogdana Szlachty, patrona „Poliarchii”, oraz przedsiębiorstwa I.D.C. Polonia S.A. Bez Państwa pomocy niniejsza publikacja nie mogłaby się ukazać.

Życzymy miłej lektury i zapraszamy do kontaktu. 